\title{
ASYMMETRY OF THE NERVOUS SYSTEM IN THE LARVA OF HARPYIA.
}

BY ANNA KATHERINA DIMMOCK, CAMBRHDGE, MASS.

Nothing has been published in regard to asymmetry of the nervous system of arthropoda, as far as I have been able to ascertain.

In dissecting a number of the larvae of Harpyia (Bombyx) vinula, I found that the nervous system, instead of extending in a direct line in the ventral region of the larva, as is common in insect larvae, curved outward laterally between the first and second thoracic ganglia, as seen between $c$ and $d$ in figure 6. This curving, which was toward the left in six larvae examined, is to avoid interference with the duct from a sac, or gland, which opens out between the first and second thoracie ganglia. This gland, represented in the figure by a dotted line, secretes a liquid, said to contain salicylic acid, which the larva ejects, as a means of defense, when disturbed. The duct of this gland opens by a transverse cleft, figured by Müller, ${ }^{1}$ on the ventral side of the first segment posterior to the head. Further details in regard to this gland are unnecessary as a good description of it has been given already by Rengger. ${ }^{2}$

In the earlier stages of the larvae of Harpyia, the nervous system turns considerably out of the direct line, in order to allow the duct of the gland to pass,

I O. F. Miiller. Pile-Larven med dobbelt Hale, og dens Phalaene ... Kjobenhavn, 1772, pl. 2, fig. $3, d$.'

2 J. R. Rengger. Physiologische Untersuchungen ïber die thierische Haushaltung der Insecten. Tübing. en, 1817 , p. $35-36$. as can be seen in figure 6 , which represents the condition in a half-grown larva; but, in the full-grown or nearly full-grown larvae, the nervous system is nearly straight, altho it is still distinctly unsymmetrical. This lessening of asymmetry, as the larva grows, is due

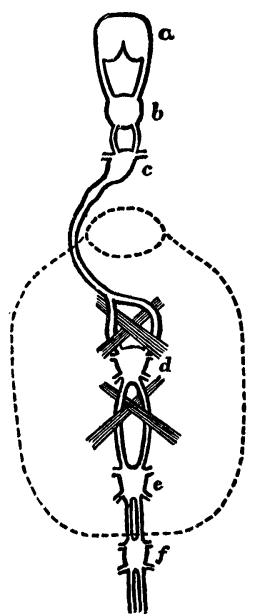

Fig. 6.-View of anterior portion of central nervous system of larva of Harpyia vinula as seen from above: $a$, supraoesophageal ganglion; $b$, infraoesophageal ganglion; $c, d$, and $e$, thoracic ganglia; $f$, first abdominal ganglion. Dotted line represents gland mentioned in text. Enlarged 6 times.

to the duct being somewhat smaller in larger larvae, in proportion to the size of the larva, thus allowing the nervous system to settle back, more or less, into its normal position.

The commissures connecting the first and second thoracic ganglia $(c$ and $d$ ) are united three-fourths of their entire 
length, separating at the posterior fourth to admit the passage of muscles which are described later. The united commissures are slightly enlarged posterior to the first thoracic ganglion $(c)$.

The muscles which cross each other between the commissures connecting the first and second and second and third thoracic ganglia are generally found in lepidopterous larvae, and serve to hold the second and third thoracic ganglia in the median line. The mode in which these muscles cross each other and interlace the commissures, as seen in the figure, is the same between the second and third as between the first and second thoracic ganglia. This mode of interlacing of the muscles and commissures is exactly the same in the larva of Sphinx ocellata as it is in that of Harpyia.

The kind of asymmetry existing in the nervous system of the larva of Har- pyia has been found, as far as I know, in no other arthropod, but, upon suggestion of Professor Leuckart, of Leipzig, in whose laboratory I was studying when I discovered the asymmetry in the nervous system of the larva of Harpyia, I examined Hirudo medicinalis, the blood-leech, the nervous system of which has an analogous asymmetry. The genital organs are in such a position, in Hirudo, as to necessitate the pushing of the nervous system slightly to one side, near their outlet.

Of four specimens of Hirudo examined, two had the nervous system to the right and two to the left of the genital organs; but of six specimens of Harpyia dissected, all had the commissure between the first and second thoracic ganglia deflected toward the left.

Paris, France, 3 Dec. 1881.

\section{NOTE ON CATOGENUS RUFUS.}

BY GLOROE DIMMOCK, (AMBRID(AE, MASN.

In the winter of $1878-1879$ I received, from Suffield, Conn., a lot of nearly full-grown larvae of Elaphidion parcllel$u m$ in twigs of Carya alba. One of these larvae, in a portion of a twig split in two parts which were carefully and tightly held together by a rubber band, was reserved upon my writing-table for the purpose of taking notes on its transformations. This larva pupated in the early part of March, and was then in an apparently healthy condition.

A short time after the larva of Elaphidion had puipated, a small white larva made its appearance in the cavity of the wood, in which the pupa was confined. As the pupa seemed in no way injured I could not determine whether or not the larva had hatched from an egg within the pupa. This larva was shown at the 58th meeting of the Cambridge entomological club. It was then very small and had the appearance of being lepidopterous. Supposing it to be the larva of some kind of museum pest that had, in a mysterious way, gained access to the pupa, I took no description or figure of it. It grew slowly, devouring the pupa 

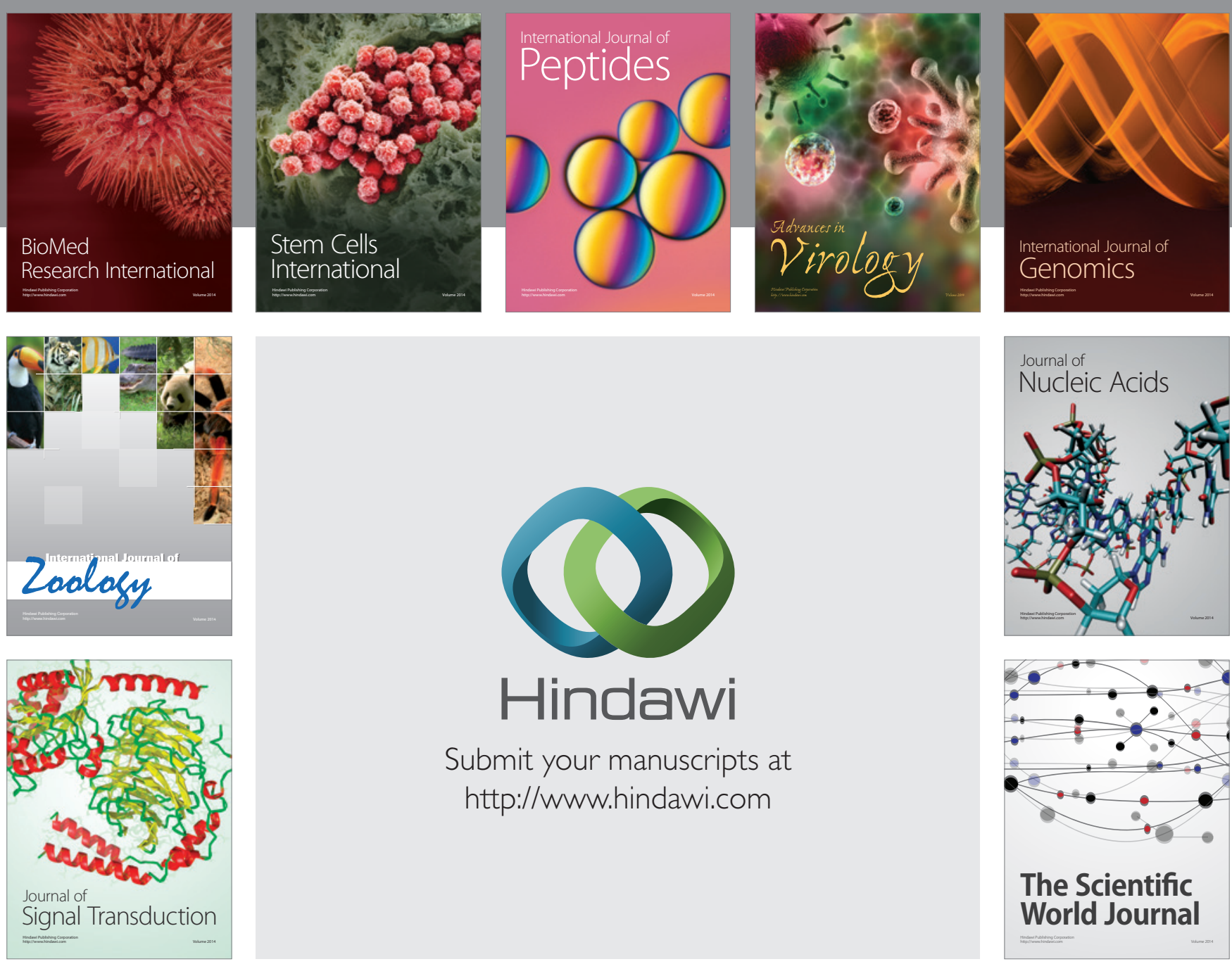

Submit your manuscripts at

http://www.hindawi.com
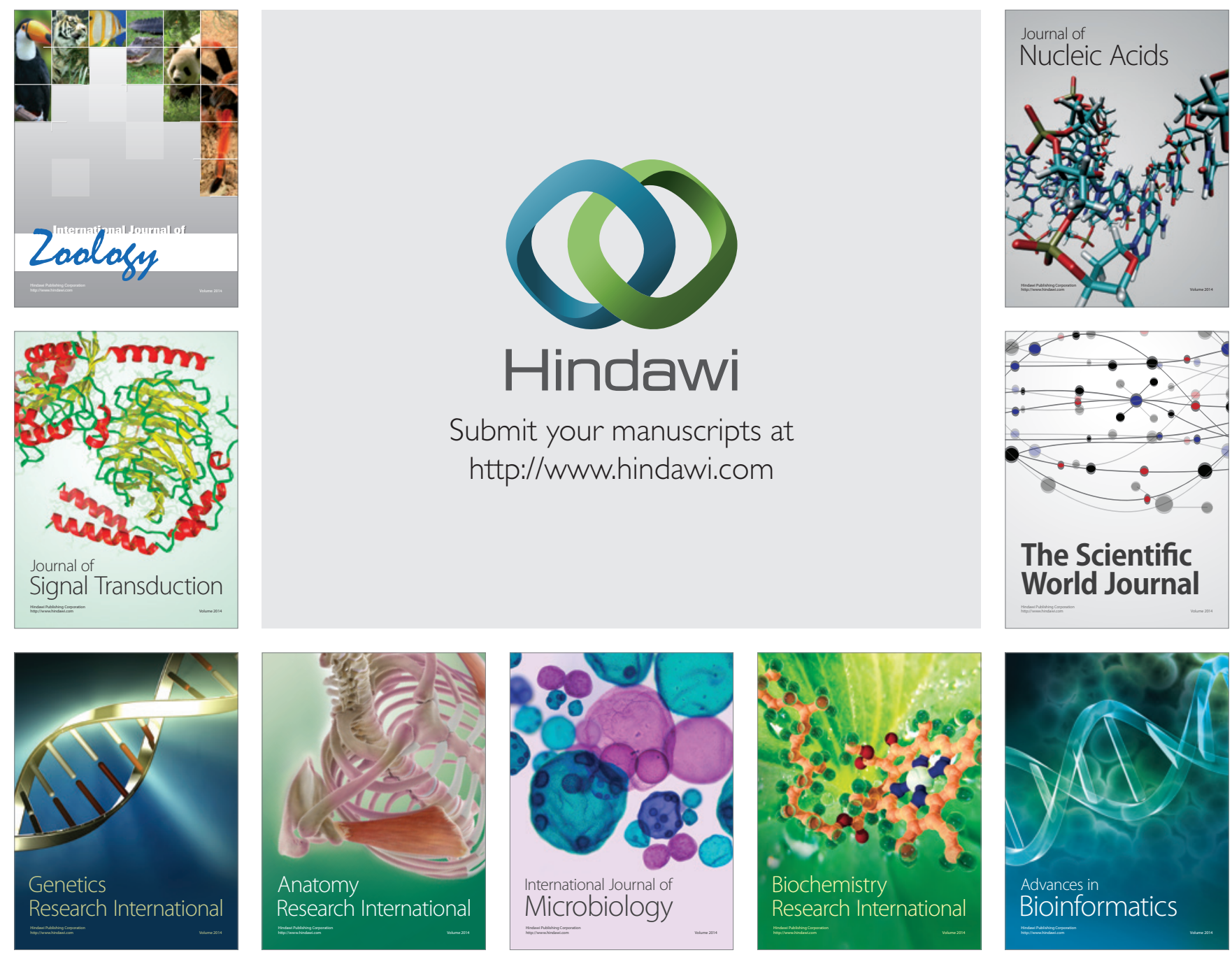

The Scientific World Journal
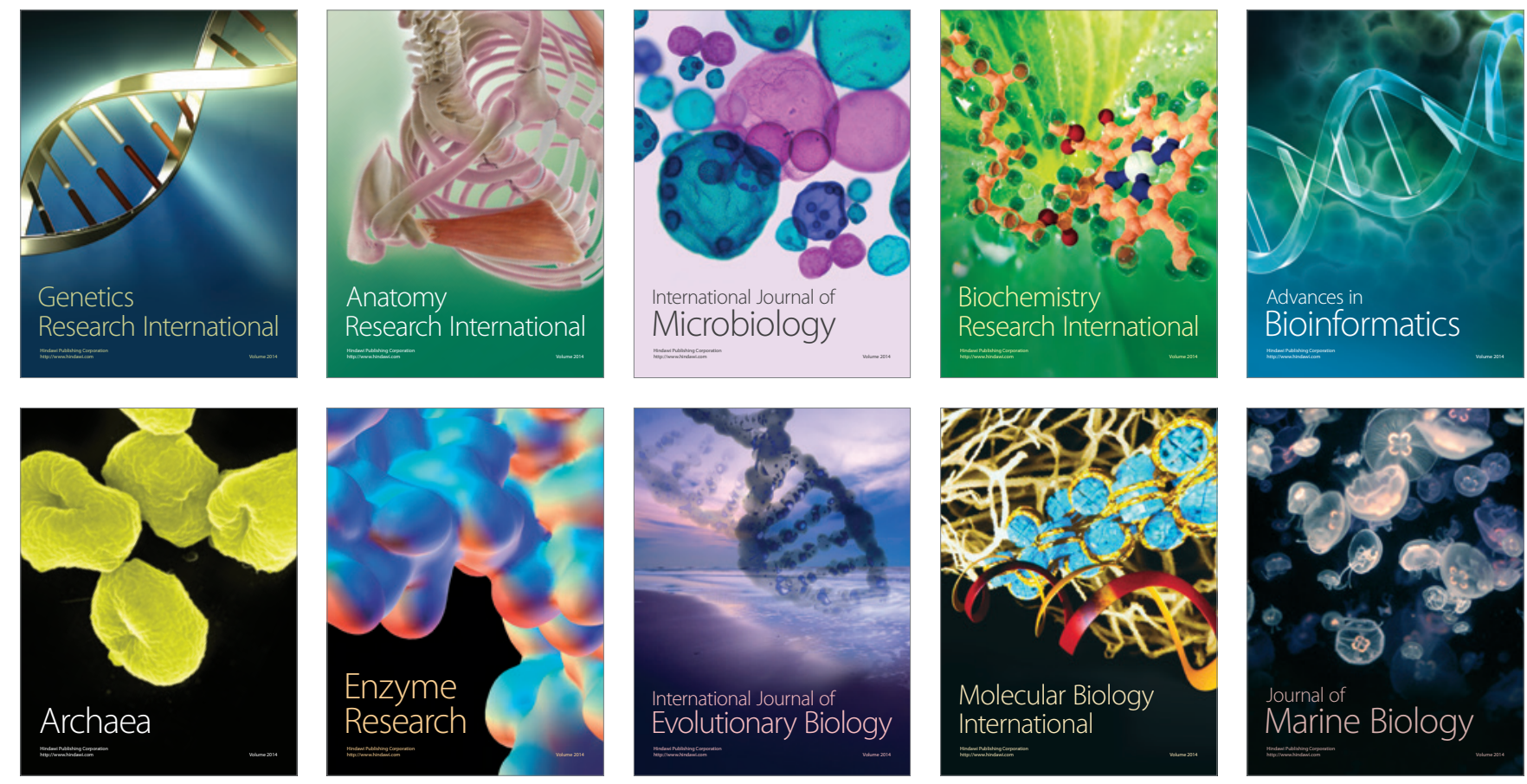